\title{
Nitrogen bonding, stability, and transport in AION films on Si
}

\author{
G. V. Soares, ${ }^{\text {a) }}$ K. P. Bastos, R. P. Pezzi, L. Miotti, and C. Driemeier \\ Instituto de Física, UFRGS, CP 15051 Porto Alegre 91501-970, Brazil \\ I. J. R. Baumvol \\ Centro de Ciencias Exatas e Tecnologicas, UCS, Caxias do Sul 95070-560, Brazil \\ C. Hinkle and G. Lucovsky \\ Department of Physics, North Carolina State University, Raleigh, North Carolina 27695-8202
}

(Received 6 February 2004; accepted 21 April 2004; published online 28 May 2004)

\begin{abstract}
The chemical environment of $\mathrm{N}$ in nitrided aluminum oxide films on $\mathrm{Si}(001)$ was investigated by angle-resolved $\mathrm{x}$-ray photoelectron spectroscopy. Two different bonding configurations were identified, namely $\mathrm{N}-\mathrm{Al}$ and $\mathrm{N}-\mathrm{O}-\mathrm{Al}$, suggesting the formation of the $\mathrm{AlN}$ and $\mathrm{AlO}_{2} \mathrm{~N}$ compounds. The near-surface region is N-rich and AlN compounds therein are more abundant than $\mathrm{AlO}_{2} \mathrm{~N}$, whereas in bulk regions the proportions of these two compounds are comparable. Rapid thermal annealing at $1000{ }^{\circ} \mathrm{C}$ for $10 \mathrm{~s}$ in vacuum or in low-pressure oxygen atmosphere led to the breakage of $\mathrm{N}-\mathrm{Al}$ bonds in AlN, releasing $\mathrm{N}$ and Al. The mobile $\mathrm{N}$ is partly lost by desorption from the surface and partly fixed by reacting with the network to form $\mathrm{AlO}_{2} \mathrm{~N}$. The released $\mathrm{Al}$ atoms, which remain immobile, react with oxygen from the film or from the gas phase. Characterization of the films outermost surfaces by low-energy ion scattering revealed that the migration of $\mathrm{Si}$ atoms from the substrate across the films, reaching the surface and being oxidized therein, is not entirely inhibited in $\mathrm{AlON} / \mathrm{Si}$, although this migration is largely reduced as compared to nonnitrided $\mathrm{Al}_{2} \mathrm{O}_{3}$ films. (C) 2004 American Institute of Physics. [DOI: 10.1063/1.1763230]
\end{abstract}

The use of a high- $k$ material replacement for silicon dioxide and oxynitride gate dielectrics in advanced ultra-large scale integration technology ${ }^{1,2}$ presents several difficulties concerning the interface density of electronic states, reliability, chemical, and structural (crystallization) stability in further processing steps, oxidation of the Si substrate, migration of boron and metallic species into the active semiconductor region, transport of Si into the high- $k$ film, and formation of voids. Recent investigations ${ }^{3-8}$ indicated that $\mathrm{N}$ incorporation either during or after deposition, by plasma or thermal processing, into some of the replacement materials so far considered, like $\mathrm{Al}, \mathrm{Y}, \mathrm{La}, \mathrm{Zr}$, and $\mathrm{Hf}$ oxides and silicates films on Si led to substantial improvements in the direction of overcoming the above-mentioned difficulties, in addition to provide lower leakage current density. However, since $\mathrm{N}$ is mainly incorporated into metastable configurations in these oxide and silicate films, ${ }^{3,7,9}$ their integration into the metal-oxide-semiconductor field-effect transistor fabrication process flow relies on the particular characteristics of $\mathrm{N}$ incorporation (concentrations and profiles) and its stability in the materials during further processing steps. In the particular case of aluminum oxide films on $\mathrm{Si}$, nitridation was achieved $^{4,10}$ and atomic scale investigation of the thermal stability of nitrided films was reported in a recent publication. ${ }^{11}$ This previous study indicated the need for clarification of the chemical situation of $\mathrm{N}$ in nitrided aluminum oxide films on $\mathrm{Si}$ and of its chemical stability in further thermal processing steps following the gate dielectric deposition. In the present letter we undertake this investigation, aiming specifically at nitrogen chemical bonding and stabil-

${ }^{a)}$ Electronic mail: gvsoares@if.ufrgs.br ity and at the use of highly sensitive surface analyses techniques to test the outstanding atomic immobility of $\mathrm{Al}$ and $\mathrm{Si}$ revealed in previous investigations.

Starting samples were 12-nm-thick $\mathrm{Al}_{2} \mathrm{O}_{3}$ films deposited on $\mathrm{Si}(001)$ by remote plasma-enhanced chemical vapor deposition ${ }^{4,11}$ and subsequently submitted to remote plasmaassisted nitridation in ${ }^{15} \mathrm{~N}_{2}$ (hereafter called as-prepared samples). Previous analyses ${ }^{11}$ showed that this preparation route leads to $\mathrm{AlO}^{15} \mathrm{~N}$ films on $\mathrm{Si}$ with an average concentration of approximately 2 at. $\%{ }^{15} \mathrm{~N}\left(\mathrm{AlO}^{15} \mathrm{~N} / \mathrm{Si}\right)$. The thermal stability of the formed structures was investigated by simulating one critical processing step, namely the source and drain dopant activation, here performed by rapid thermal annealing (RTA) at $1000{ }^{\circ} \mathrm{C}$ for $10 \mathrm{~s}$, either in vacuum (1 $\left.\times 10^{-7} \mathrm{mbar}\right)$ or in $\mathrm{O}_{2}$-containing atmosphere (70 mbar of $98.5 \%{ }^{18} \mathrm{O}$-enriched $\mathrm{O}_{2}$, termed ${ }^{18} \mathrm{O}_{2}$-annealing). Since ${ }^{18} \mathrm{O}$ is a rare isotope, it can be distinguished from the oxygen atoms previously existing in the films when ${ }^{18} \mathrm{O}_{2}$-annealing is performed. Chemical bonding was investigated, before and after RTA, by x-ray photoelectron spectroscopy (XPS) in an OMICRON-EA125 station, using $\mathrm{Mg} K \alpha$ radiation (1253.6 $\mathrm{eV}$ ), with an overall resolution of $0.9 \mathrm{eV}$. Elementary analysis of the surface was performed by means of low energy ion scattering using $1 \mathrm{keV} \mathrm{He}^{+}$ions.

Figure 1(a) shows the $\mathrm{N} 1 s$ photoelectron energy regions at $45^{\circ}$ take-off angle for the as-prepared sample and for the samples annealed in vacuum and in ${ }^{18} \mathrm{O}_{2}$. Two different components are identified for the as-prepared sample: one of them, at a binding energy $E_{b}=398 \mathrm{eV}$, can be assigned to $\mathrm{N}-\mathrm{Al}^{12,13}$ bonding, whereas the other, at $E_{b}=402.2 \mathrm{eV}$, can be assigned to $\mathrm{N}-\mathrm{O}-\mathrm{Al}$ bonding ${ }^{14,15}$ (hereafter called $\mathrm{N}-\mathrm{O}$ bonding). One notices that vacuum or ${ }^{18} \mathrm{O}_{2}$-annealing lead to an increase of the $\mathrm{N}-\mathrm{O}$ component with respect to the $\mathrm{N}-\mathrm{Al}$ 


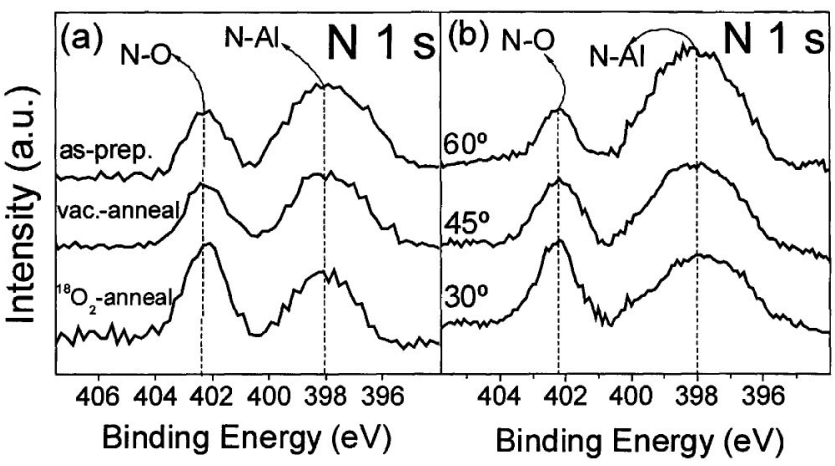

FIG. 1. N $1 s$ photoelectron regions (a.u.= arbitrary units) for $\mathrm{AlO}^{15} \mathrm{~N}$ films on $\mathrm{Si}(001)$ : (a) as-prepared and vacuum and ${ }^{18} \mathrm{O}_{2}$-annealed samples at $1000{ }^{\circ} \mathrm{C}$ for $10 \mathrm{~s}$. Take-off angle: $45^{\circ}$; (b) as-prepared sample at take-off angles of $30^{\circ}, 45^{\circ}$, and $60^{\circ}$.

component. The increase in the $\mathrm{N}-\mathrm{O} / \mathrm{N}-\mathrm{Al}$ intensity ratio is much larger after ${ }^{18} \mathrm{O}_{2}$ annealing than after vacuum annealing. Figure 1(b) shows the $\mathrm{N} 1 s$ photoelectrons from the asprepared sample for three different take-off angles, namely $60^{\circ}$ (surface-sensitive), $45^{\circ}$, and $30^{\circ}$ (bulk-sensitive). In near-surface regions of the film, the spectral area of the $\mathrm{N}-\mathrm{Al}$ component is much larger than that of the $\mathrm{N}-\mathrm{O}$ component, whereas in bulk regions the $\mathrm{N}-\mathrm{Al}$ spectral area decreases significantly, becoming comparable to that of $\mathrm{N}-\mathrm{O}$. The $\mathrm{Al} 2 p$ photoelectron region (not shown) for the asprepared sample is similar to that of an $\mathrm{Al}_{2} \mathrm{O}_{3}$ environment and the annealed samples do not show any discernable difference from the as-prepared one. The Al $2 p$ energy shifts for $\mathrm{AlN}, \mathrm{Al}_{2} \mathrm{O}_{3}$ and $\mathrm{AlON}^{12,14-16}$ are smaller $(\sim 0.2 \mathrm{eV})$ than the resolution of the equipment $(0.9 \mathrm{eV})$ and therefore no information about the chemical state of $\mathrm{N}$ can be obtained from the $\mathrm{Al} 2 p$ region.

One can use calculations ${ }^{17}$ of $\mathrm{N} 1 s$ core levels for silicon nitride $\left(\mathrm{Si}_{3} \mathrm{~N}_{4}\right)$ and silicon oxynitride $\left(\mathrm{SiO}_{x} \mathrm{~N}_{y}\right)$ films and the energy shifts of the $\mathrm{N} 1 s$ core level for different microscopic structures and bonding configurations to interpret the large energy difference of $4.2 \mathrm{eV}$ observed here between the $\mathrm{N}-\mathrm{Al}$ and the $\mathrm{N}-\mathrm{O}$ components. This is justified since (i) $\mathrm{Si}$ and $\mathrm{Al}$ have similar electronegativities, differing only by 0.3 and (ii) similar energy shifts to those presented in Fig. 1 were observed $^{18}$ in $\mathrm{N} 1 s$ photoelectrons for silicon oxynitride films on $\mathrm{Si}$. Thus, by analogy with the $\mathrm{Si}_{3} \mathrm{~N}_{4}$ and $\mathrm{SiO}-\mathrm{N}$ compounds, in the present case the observed shift can be attributed to the coexistence of $\mathrm{AlN}$ and $\mathrm{AlO}_{2}-\mathrm{N}$, such that the as-prepared $\mathrm{AlO}^{15} \mathrm{~N} / \mathrm{Si}$ structures of the present work contain a mixture of $\mathrm{AlO}_{2} \mathrm{~N}$ and AlN.

The increase in the $\mathrm{N}-\mathrm{O} / \mathrm{N}-\mathrm{Al}$ intensity ratio after RTA can be attributed to the breakage of metastable $\mathrm{N}-\mathrm{Al}$ bonds. According to the angle-resolved XPS data of Fig. 1(b), they are more abundant in the near-surface region. This is in full agreement with Ref. 11, where a strong $\mathrm{N}$ loss from the previously $\mathrm{N}$-rich near-surface region was observed after vacuum and ${ }^{18} \mathrm{O}_{2}$ RTAs. The ${ }^{18} \mathrm{O}_{2}$ atmosphere annealing enhances the nitrogen loss due to $\mathrm{N}-\mathrm{O}$ exchange. ${ }^{11}$ The released $\mathrm{N}$ partly diffuses and desorbs from the film surface and partly reacts with the $\mathrm{Al}_{2} \mathrm{O}_{3}$ network forming $\mathrm{AlO}_{2} \mathrm{~N}$ ( $\mathrm{N}-\mathrm{O}$ bonds). The released $\mathrm{Al}$ atoms remain in the film, reacting with oxygen either from the film or from the gas Downloaded 22 Feb 2008 to 152.1.190.114. Redistribution subject

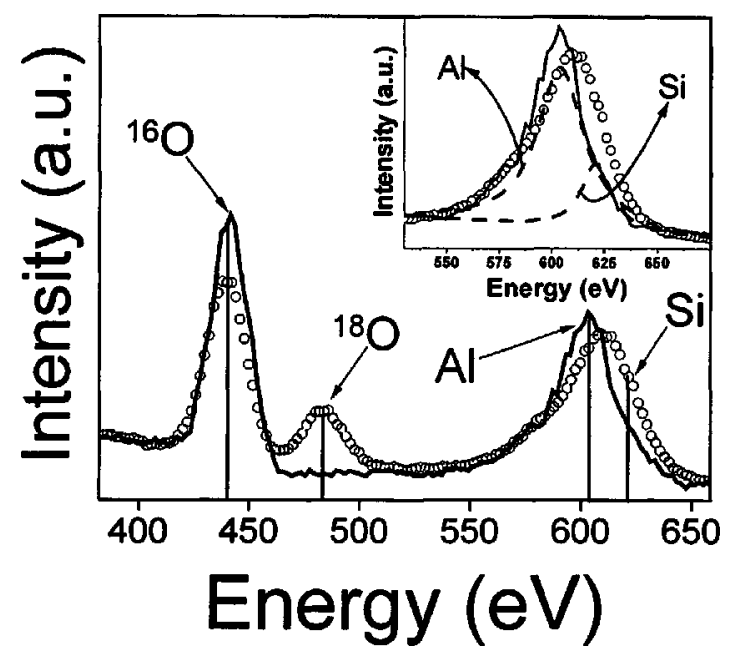

FIG. 2. Low energy ion scattering spectra of $\mathrm{He}^{+}$ions (incidence energy: $1000 \mathrm{eV}$ ) from $\mathrm{AlO}^{15} \mathrm{~N}$ films on $\mathrm{Si}$. As-prepared sample (solid line), ${ }^{18} \mathrm{O}_{2}$-annealed sample at $1000{ }^{\circ} \mathrm{C}$ for $10 \mathrm{~s}$ (open circles). The lines indicate the energy regions corresponding to $\mathrm{He}^{+}$scattered from the different atomic species present in the surface of the films. The inset shows the $\mathrm{Si}$ and $\mathrm{Al}$ contributions to the spectra, represented by dashed lines.

phase. This is again in accordance with the results from Ref. 11 in which no changes in the $\mathrm{Al}$ profile were detected after either vacuum or ${ }^{18} \mathrm{O}_{2}$ annealings.

Since the reported immobility of $\mathrm{Al}$ and $\mathrm{Si}$ in $\mathrm{AlON} / \mathrm{Si}$ after annealing in $\mathrm{O}_{2}$-containing atmospheres ${ }^{11}$ was in full contrast with previous results for $\mathrm{Al}_{2} \mathrm{O}_{3} / \mathrm{Si}^{19}$ as well as for other metal oxide and silicate films on $\mathrm{Si}^{20-22}$ further verification of this highly desirable stability is necessary. With this aim, a much more sensitive, surface selective technique was used here, namely low energy ion scattering (LEIS) of $1000 \mathrm{eV} \mathrm{He}^{+}$ions. Figure 2 shows the LEIS spectra for the as-prepared and ${ }^{18} \mathrm{O}_{2}$-annealed samples. While the LEIS spectrum for the as-prepared sample does not show evidence of $\mathrm{Si}$ at the surface, in the ${ }^{18} \mathrm{O}_{2}$-annealed sample there is an enhancement of the LEIS signal in the energy region corresponding to scattering of $\mathrm{He}^{+}$ions from $\mathrm{Si}$ atoms, indicating the presence of Si atoms in the surface of the film. Owing to the much higher sensitivity of LEIS to Si as compared to the nuclear reaction methods used in Ref. 11, one can say that there is still migration of substrate-Si atoms toward the surface, although this is largely reduced in nitrided $\mathrm{Al}_{2} \mathrm{O}_{3}$ films as compared to non-nitrided ones. Oxygen isotopic exchange at the film surface is also apparent from the LEIS spectra for the ${ }^{18} \mathrm{O}_{2}$-annealed samples. Another striking fact revealed by Fig. 2 is the absence of any signal in the energy region corresponding to scattering of $\mathrm{He}^{+}$ions from $\mathrm{N}$, both for the as-prepared and ${ }^{18} \mathrm{O}_{2}$-annealed samples. This observation indicates that $\mathrm{N}$ resides always in subsurface sites and is thus shielded from the incident $\mathrm{He}^{+}$ions, a fact that has already been observed before ${ }^{23}$ in the case of nitridation of $\mathrm{Si}$ in $\mathrm{NH}_{3}$.

Si $2 p$ photoelectron energy regions are shown in Fig. 3 for the same $\mathrm{AlO}^{15} \mathrm{~N} / \mathrm{Si}$ samples of Fig. 1(a). In the asprepared sample the flat background photoelectron signal confirms the absence of $\mathrm{Si}$ in near surface regions. Since the $\mathrm{AlO}^{15} \mathrm{~N}$ films are $12 \mathrm{~nm}$ thick, no photoelectrons originating either from the $\mathrm{AlO}^{15} \mathrm{~N} / \mathrm{Si}$ interface or from the substrate are expected to appear. However, after annealing the samples in to AIP license or copyright; see http://apl.aip.org/apl/copyright.jsp 


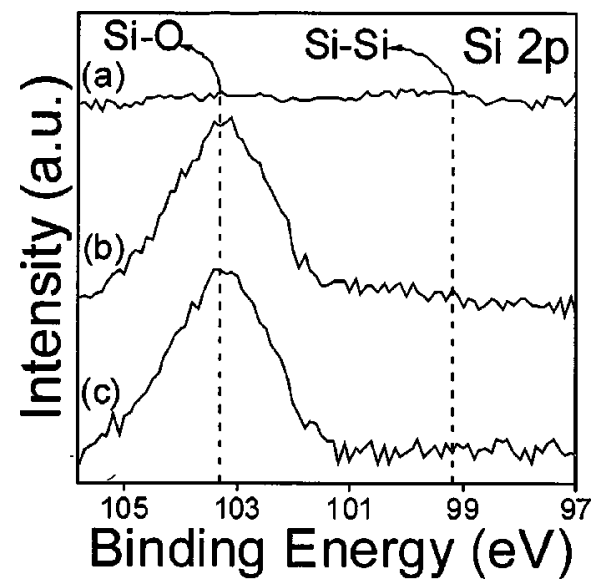

FIG. 3. Si $2 p$ photoelectron regions (a.u. $=$ arbitrary units) at a take-off angle of $45^{\circ}$ for $\mathrm{AlO}^{15} \mathrm{~N}$ films on $\mathrm{Si}(001)$ : (a) as-prepared; (b) vacuum annealed, and (c) ${ }^{18} \mathrm{O}_{2}$ annealed.

vacuum or in ${ }^{18} \mathrm{O}_{2}$, there is a photoelectron intensity peak at $E_{b}=103.2 \mathrm{eV}$, which is clearly due to the presence of $\mathrm{Si}-\mathrm{O}$ bonding in $\mathrm{SiO}_{2}$. On the other hand, these spectra show no evidence of intensity peak around $E_{b}=99 \mathrm{eV}$, which would be indicative of the presence of $\mathrm{Si}-\mathrm{Si}$ bonding. Combining these results with the LEIS data presented in Fig. 2, one can say that substrate-Si atoms migrate across the film reaching the surface, reacting therein with oxygen from the film or from the gas phase, forming $\mathrm{SiO}_{2}$. This fact has been previously reported ${ }^{19}$ for $\mathrm{Al}_{2} \mathrm{O}_{3}$ films on $\mathrm{Si}$.

In summary, we have studied the chemical environment of $\mathrm{N}$ and its thermal stability in further processing steps in AlON films on Si. Nitrogen is present in two different compounds, namely $\mathrm{AlN}$ and $\mathrm{AlO}_{2} \mathrm{~N}$. In near-surface regions, AlN is more abundant than $\mathrm{AlO}_{2} \mathrm{~N}$, whereas in bulk regions the proportions of these two compounds are comparable. Annealing in oxygen or in vacuum led to the breakage of $\mathrm{N}-\mathrm{Al}$ bonds in AlN, releasing $\mathrm{N}$ and $\mathrm{Al}$. The mobile $\mathrm{N}$ is partly lost by desorption from the surface and partly fixed by reacting with the network to form $\mathrm{AlO}_{2} \mathrm{~N}$. Furthermore, nitrogen loss is increased during ${ }^{18} \mathrm{O}_{2}$ annealing due to exchange between $\mathrm{N}$ from the film and oxygen from the gas phase. The released $\mathrm{Al}$ atoms, which remain immobile, react with oxygen from the film or from the gas phase. Finally, the migration of $\mathrm{Si}$ atoms from the substrate across the films, reaching the sur- face and being oxidized therein is not entirely inhibited in $\mathrm{AlON} / \mathrm{Si}$, although this migration is largely reduced as compared to non-nitrided $\mathrm{Al}_{2} \mathrm{O}_{3}$ films.

The authors would like to thank Dr. Fernanda C. Stedile for helpful discussions. Financial support from CNPq, CAPES, and FAPERGS is acknowledged.

${ }^{1}$ G. D. Wilk, R. M. Wallace, and J. M. Anthony, J. Appl. Phys. 89, 5243 (2001).

${ }^{2}$ High-k Gate Dielectrics, edited by M. Houssa (IOP, London, 2004).

${ }^{3}$ G. Shang, P. W. Peacock, and J. Robertson, Appl. Phys. Lett. 84, 106 (2004).

${ }^{4}$ C. Hinkle and G. Lucovsky, Appl. Surf. Sci. 216, 124 (2003).

${ }^{5}$ M. S. Akbar, S. Gopalan, H.-J. Cho, K. Onishi, R. Choi, R. Nieh, C. S. Kang, Y. H. Kim, J. Han, S. Krishnan, and J. C. Lee, Appl. Phys. Lett. 82, 1757 (2003)

${ }^{6}$ Y. Fujisaki, K. Iseki, H. Ishiwara, M. Mao, and R. Bubber, Appl. Phys. Lett. 82, 3931 (2003).

${ }^{7}$ K. P. Bastos, J. Morais, L. Miotti, R. P. Pezzi, G. V. Soares, I. J. R. Baumvol, H.-H. Tseng, R. I. Hedge, and P. J. Tobin, Appl. Phys. Lett. 81, 1669 (2002).

${ }^{8}$ M. Quevedo-Lopez, M. El-Bouanani, M. J. Kim, B. E. Gnade, R. M. Wallace, M. R. Visokay, A. Lifatou, J. J. Chambers, and L. Colombo, Appl. Phys. Lett. 82, 4669 (2003).

${ }^{9}$ C. S. Kang, H.-J. Cho, K. Onishi, R. Choi, R. Nieh, S. Gopalan, S. Krishman, J. H. Han, and J. C. Lee, Appl. Phys. Lett. 81, 2593 (2002).

${ }^{10}$ S. Guha, E. P. Gusev, H. O-Schmidt, M. Copel, L.-A. Ragnarsson, and P. Ronsheim, Appl. Phys. Lett. 81, 2956 (2002).

${ }^{11}$ K. P. Bastos, R. P. Pezzi, L. Miotti, G. V. Soares, C. Driemeier, J. Morais, I. J. R. Baumvol, C. Hinkle, and G. Lucovsky, Appl. Phys. Lett. 84, 97 (2004).

${ }^{12}$ A. D. Katnani and K. I. Papathomas, J. Vac. Sci. Technol. A 5, 1335 (1987).

${ }^{13}$ J. A. Taylor and J. W. Rabalais, J. Chem. Phys. 75, 1735 (1981).

${ }^{14}$ Y. Cho, Y. Kim, E. R. Weber, S. Ruvimov, and Z. Liliental-Weber, J. Appl. Phys. 85, 7909 (1999).

${ }^{15}$ J. A. Kovacich, J. Kasperkiewicz, D. Lichtman, and C. R. Aita, J. Appl. Phys. 55, 2935 (1984).

${ }^{16}$ H. M. Liao, R. N. S. Sodhi, and T. W. Coyle, J. Vac. Sci. Technol. A 11, 2681 (1993)

${ }^{17}$ G.-M. Rignanese, A. Pasquarello, J.-C. Charlier, X. Gonze, and R. Car, Phys. Rev. Lett. 79, 5174 (1997).

${ }^{18}$ D. Landheer, Y. Tao, D.-Xu. Xu, G. I. Sproule, and D. A. Buchanan, J. Appl. Phys. 78, 1818 (1995).

${ }^{19}$ C. Krug, E. B. O. da Rosa, R. M. C. de Almeida, J. Morais, I. J. R. Baumvol, T. D. M. Salgado, and F. C. Stedile, Phys. Rev. Lett. 85, 4120 (2000).

${ }^{20}$ J. A. Gupta, D. Landheer, J. P. McCaffrey, and G. I. Sproule, Appl. Phys. Lett. 78, 1718 (2001).

${ }^{21}$ J. J. Chambers and G. N. Parsons, Appl. Phys. Lett. 77, 2385 (2000).

${ }^{22}$ J. Morais, E. B. O. da Rosa, R. P. Pezzi, L. Miotti, and I. J. R. Baumvol, Appl. Phys. Lett. 79, 1998 (2001).

${ }^{23}$ F. Bozso and Ph. Avouris, Phys. Rev. Lett. 57, 1185 (1986). 